\title{
A Structural Analysis of the Physician- Patient Relationship in No-Code Decisionmaking
}

When hospital personnel discover that a patient has suffered a cardiopulmonary arrest, ${ }^{1}$ they usually summon a team of doctors and nurses trained in advanced cardiopulmonary resuscitation (CPR). ${ }^{2}$ Physicians may, however, instruct personnel not to attempt resuscitation by assigning a "no-code order."

This Note criticizes current no-code decisionmaking and urges replacing it with a system based upon informed consent by the patient. An analysis of the roles of the actors involved in the no-code system indicates that the patient is usually the most appropriate decisionmaker. Current efforts to reform hospital policies ${ }^{4}$ or resort to third-party adjudications ${ }^{5}$ unwisely limit patient control of the no-code decision. The Note proposes both that prolongation of life should remain a choice even for the terminally ill patient and that no-code status should be an option for a competent patient who is not terminally ill. To maximize patient autonomy and selfdetermination for no-code decisionmaking, the Note recommends that the physician elicit an informed decision at the time of hospital admission and that the hospital formally monitor the implementation of that decision.

1. Typically, a nurse discovers a patient whose breathing and heartbeat have stopped. Cardiopulmonary resuscitation (CPR) must then begin immediately because anoxic brain damage generally occurs within three to five minutes. The nurse summons the advanced CPR team after she has begun basic CPR (artificial ventilation and external cardiac compression). See In re Dinnerstein, 6 Mass. App. Ct. 466, 468, 380 N.E.2d 134, 135 (1978); D. Meyers, Medico-Legal Implications of DEATH AND Dying 186-87 (1981). CPR did not gain widespread use until the 1960's. See DeBard, The History of Cardiopulmonary Resuscilation, 9 ANNAls EMERGENCY MED. 273 (1980).

2. CPR consists of two types of techniques. Basic Life Support includes establishment of artificial respiratory ventilation by mouth-to-mouth resuscitation and artificial circulation by external cardiac compression. Advanced Life Support uses equipment and special techniques. See National Conference on Standards for Cardiopulmonary Resuscitation (CPR) and Emergency Cardiac Care (ECC), $244 \mathrm{~J}$. A.M.A. 453, 460-71, 479-93 (1980) [hereinafter cited as National Conference].

3. A "full code" or "complete code" instructs hospital staff to undertake a full-scale CPR effort if the patient has a cardiopulmonary arrest. A "no-code," "do-not-resuscitate," or "order not to resuscitate" instructs the nursing staff not to summon the resuscitation team if that patient has a cardiopulmonary arrest. See In re Dinnerstein, 6 Mass. App. Ct. 466, 469 n.3, 380 N.E.2d 134, 136 n.3 (1978) (describing recent development of coding systems in acute care hospitals).

4. See, e.g., President's Comm'n for the Study of Ethical Problems in Medicine and Biomedical and Eehavioral Research, Deciding To Forego Life-Sustaining Treatment 9 (1982) (proposing uniform accreditation requirements concerning no-codes) [hereinafter cited as Life-Sustaining Treatment].

5. See, e.g., Superintendent of Belchertown State School v. Saikewicz, 373 Mass. 728, 756-59, 370 N.E.2d 417, 431-35 (1977) (requiring probate court review); In re Quinlan, 70 N.J. 10, 49-50, 355 A.2d 647, 668-69 (proposing hospital ethics committee), cert. denied, 429 U.S. 922 (1976). 


\section{Gurrent CPR Medical Practices and Informed Consent}

The physician's discretion in assigning no-code status limits the influence of a patient's desires. Courts do not currently require physicians to adhere strictly to the informed consent doctrine in making coding decisions, and their current reliance upon a physician's coding decisions results in outcomes that reflect the physician's preferences ${ }^{\mathfrak{b}}$ at the expense of the patient's rights to self-determination and participation. ${ }^{7}$

\section{A. Determining Coding Status}

No-code systems vary both among institutions and within a given hospital, ${ }^{8}$ but physicians generally limit assignment of no-code status to terminally ill patients with an irreversible condition. ${ }^{\circ}$ In determining no-code status, physicians usually consult with the patient's family, ${ }^{10}$ but rarely with the patient, even if he is competent. ${ }^{11}$ Because physicians do not us-

6. See genernlly Eisenberg, Sociologic Influences on Decision-Making by Clinicians, 90 AnNats InTERNAL MED. 957 (1979) (physician's decisionmaking process influenced by factors intrinsic to own personality and by physician's reaction to patient's personal characteristics).

7. See Goldstein, For Harold Lassuell-Some Reflections on Human Dignity, Entrapment, Informed Consent, and the Plea Bargain, 84 YALE L.J. 683, 690-95 (1975) (arguing that, when consent not informed, a citizen's dignity may be harmed even if therapy is beneficial); $c f$. Michelman, The Supreme Court and Litigation Access Fees: The Right to Protect One's Rights, 1973 Duke L.J. 1153,1175 (participation significant in determinations of due process).

8. Sep Note, No.Code Orders vs. Resuscitation: The Decision To Withold Life-Prolonging Treatment From the Terminally Ill, 26 WAYNE L. REv. 139, 143 n.21 (1979) (discussing varying medical practices).

9. One court has specifically ruled that assignment of no-code status in this category of patients is a discretionary decision by the physician. See In re Dinnerstein, 6 Mass. App. Ct. 466, 475, 380 N.E.2d 134, 139 (1978) (no-code decision within competence of medical profession).

10. See id. (decision to code within physician's discretion in light of, inter alia, family's wishes); National Conference, supra note 2, at 507 (recommending assignment of no-code after discussion with patient's family). But spe J. Robertson, The Rights of THE CRITICally ILL 74 (1983) (some doctors do not inform families of no-code orders).

11. See J. RobertSon, supra note 10, at 77 (some physicians view obtaining competent patients' consent for no-code orders as violation of standards of care). Studies demonstrate that over $80 \%$ of physicians do not even discuss the threshold issue of terminal prognoses with their patients. See Veatch, When Should the Patient Know? When Should He Be Kept in the Dark?, 1981 BARRISTER 6, 6. Physicians may honor a terminally ill patient's unsolicited request for a no-code status. Without active inquiry by the physician, however, such a patient request is unlikely because of the anxiety and ignorance of most patients. See J. RoBERTSON, supra note 10 , at 77 (patient extremely unlikely to inquire of own accord); $c$. Canterbury v. Spence, 464 F.2d 772, 781 (D.C. Cir.) (noting informed consent requires affirmative physician duty of disclosure because few patients could otherwise ask cogent questions), cert. denied, 409 U.S. 1064 (1972). A fully coded terminally ill patient may receive CPR without his prior consent or the consent of his family. Because physicians treat all silent nonterminally ill patients as fully coded, these patients almost always receive CPR without prior consent. See Guidelines for Do Not Resuscitate Orders, Northuestern Memorial Hospital, Chicago, in LEGal. and Ethical Aspects of Treating Critically and Terminally Ill Patients 303 (1982) (all patients not designated "no-code" treated as "full-code") (hereinafter cited as LEGAL AND ETHICAL Aspects]; Van Scoy-Mosher, An Oncologisl's Case for No-Code Orders, in Legal and Ethical. ASPECTs, supra, at 16 (noting full code is automatic and does not require an order). Physicians can choose not to honor an unsolicited no-code request by a non-terminally ill patient. See, e.g., R. BuRT, Taking Care of Strangers 1-6 (1979) (describing David G., a severe burn victim, whom physicians refused to no-code despite his personal pleas and his poor initial prognosis); D. CRANE, ThE 
ually assign no-code status until a patient is near death, patient participation is often impracticable. By that time, the patient's incompetence may obviate obtaining patient consent. ${ }^{12}$

\section{B. Legal Constraints on Coding Decisions}

Although medical discretion in determining coding status is ostensibly constrained by the doctrine of informed consent, courts fail to demand strict informed consent requirements, and other tort causes of action are ineffective.

\section{Informed Consent}

Over the past twenty-five years, courts have established a qualified requirement ${ }^{13}$ that physicians inform their patients about the nature and risks of proposed therapies and available alternatives. ${ }^{14}$ Despite the recent expansion of the informed consent doctrine to a wide range of medical interventions, ${ }^{18}$ the courts do not enforce strict informed consent requirements in no-code decisionmaking. This reluctance stems from a judicial misperception that there are no patient choices involved in no-coding and that informed consent is impracticable for CPR procedures contingent upon an unpredictable future event. In the leading decision on no-code

Sanctity of Social life: Physicians' Treatment of Critically Ill Patients 82 (1978) (describing incident in which resuscitation of 80 -year-old retired nurse against her will generated conflict between nurses and medical staff).

12. See J. Robertson, supra note 10, at 77 (patient likely to be incompetent when no-code decision made). Almost all patients become incompetent at some time before a cardiopulmonary arrest. A physician at the scene of a cardiopulmonary arrest may exercise medical judgment to determine the intensity of the CPR effort. See AMERICan Heart Ass'N, TextboOK of Advanced Cardiac Life SUPPORT at XVIII-4 to XVIII-8 (1981). For example, one physician has advocated giving only fiveminute resuscitation attempts to all patients more than 65 years old. See Baer, Cardiopulmonary Resuscitation After Age 65, 43 AM. J. Cardiology 1065 (1979) (letter to the editors).

13. There are two major exceptions to the requirement of informed consent. The "therapeutic privilege" allows a physician to withhold a diagnosis from his patient when disclosure would seriously jeopardize the recovery of an unstable patient. See Canterbury v. Spence, 464 F.2d 772, 789 (D.C. Cir.), cert. denied, 409 U.S. 1064 (1972); Natanson v. Kline, 186 Kan. 393, 406, 350 P.2d 1093, 1103 (1960). The "emergency exception" allows a physician to proceed with treatment when the patient is incapable of consenting and the harm from a failure to treat exceeds possible harm from the proposed treatment. See Canterbury, 464 F.2d at 788-89; Dunham v. Wright, 423 F.2d 940, 941-42 (3d Cir. 1970). An attempt should still be made to secure a relative's consent if possible, but the physician may proceed with treatment if immediate care is required. See Canterbury, 464 F.2d at 789.

14. See, e.g., Canterbury v. Spence, 464 F.2d 772, 783-84 (D.C. Cir.) (announcing standard of disclosure independent of prevailing professional standards), cert. denied, 409 U.S. 1064 (1972); Salgo v. Leland Stanford, Jr., Univ. Bd. of Trustees, 154 Cal. App. 2d 560, 578, 317 P.2d 170, 181 (1957) (requiring disclosure of all facts necessary to form basis of informed consent); Natanson v. Kline, 186 Kan. 393, 410, 350 P.2d 1093, 1106-07 (1960) (requiring disclosure of nature of disease and proposed treatment, risks, probability of success, and availability of alternatives).

15. See, e.g., Truman v. Thomas, 93 Cal. App. 3d 304, 155 Cal. Rptr. 752 (1979) (pap smear); Salgo v. Leland Stanford, Jr., Univ. Bd. of Trustees, 154 Cal. App. 2d 560, 317 P.2d 170 (1957) (diagnostic radiology); Whitfield v. Daniel Const., 226 S.C. 37, 83 S.E.2d 460 (1954) (drug therapy). 
decisionmaking, ${ }^{16}$ the court deferred to the expertise of the medical profession under the assumption that assigning a no-code decision involves no discretion $^{17}$ unless there is some hope of restoring the terminally ill patient to a normal cognitive existence. ${ }^{18}$ Honoring a patient's wish for heroic medical intervention, such as $\mathrm{CPR}$, would recognize the intrinsic value of autonomous patient decisionmaking that should outweigh any effect on the patient's prognosis.

Courts have not required informed consent in emergencies ${ }^{18}$ or in situations in which patients may become greatly distressed as a result of the disclosures necessary for informed consent. ${ }^{20}$ Although CPR arguably falls within this emergency exception, ${ }^{21}$ determining the coding status soon after a patient enters the hospital would increase the time available for deliberation and thus minimize the need to invoke the emergency exception. ${ }^{22}$ Courts should therefore limit the emergency exception for a CPR treatment decision to cases in which GPR must begin before the patient sees a physician. ${ }^{23}$

16. In re Dinnerstein, 6 Mass. App. Ct. 466, 475, 380 N.E.2d 134, 139 (1978).

17. Id. at $474-75,380$ N.E.2d at $138-39$.

18. Id. at $466-67,380$ N.E.2d at 134-35.

19. See, e.g., Dunham v. Wright, 423 F.2d 940, 941-42 (3d Cir. 1970) (thyroid surgery for hyperthyroidism); Luka v. Lowrie, 171 Mich. 122, 133, 136 N.W. 1106, 1110 (1912) (foot amputation for infection); Grouch v. Most, 78 N.M. 406, 410, 432 P.2d 250, 254 (1967) (antivenom for rattlesnake bite).

20. See, e.g., Salgo v. Leland Stanford, Jr., Univ. Bd. of Trustees, 154 Cal. App. 2d 560, 578, 317 P.2d 170, 181 (1957) (radiological study of the aorta); Fiorentino v. Wenger, 19 N.Y.2d 407, 415-16, 227 N.E.2d 296, 300, 280 N.Y.S.2d 373, 379-80 (App. Div. 1967) (spinal fusion); Starnes v. Taylor, 272 N.C. 386, 393, 158 S.E.2d 339, 344 (1968) (diagnostic study of the esophagus).

21. The "emergency exception" to the doctrine of informed consent suspends the consent requirement when a patient is unconscious or otherwise unable to comprehend what is being said to him and when the imminent harm from a failure to treat outweighs the possible harm from the treatment. Canterbury v. Spence, 464 F.2d 772, 788 (D.C. Cir.), cert. denied, 409 U.S. 1064 (1972).

22. In cases of imminent danger to the patient, judicial decisions vary as to whether a patient has a right to refuse treatment. Compare Holmes v. Silver Cross Hosp., 340 F. Supp. 125, 129-30 (N.D. IIl. 1972) '(allowing Jehovah's Witness to refuse transfusion) and In re Estate of Brooks, 32 Ill. 2d 361, 372-74, 205 N.E.2d 435, 441-42 (1965) (same) with United States v. George, 239 F. Supp. 752, 753-54 (D. Conn. 1965) (Jehovah's Witness given transfusion when she would not actively resist court action) and Ex rel. President and Directors of Georgetown College, 331 F.2d 1000, 1009 (D.C. Cir.) (same), cert. denied, 377 U.S. 978 (1964). Where therapy is likely to be successful and nontreatment will probably be fatal, the ultimate issue becomes whether refusal of therapy constitutes suicide. See Superintendent of Belchertown State School v. Saikewicz, 373 Mass. 728, 743 n.11, 370 N.E.2d 417, 426 n.11 (1977). Performing CPR does not, however, usually prevent death. See infra note 51 (low survival-to-hospital-discharge rate). Furthermore, there is a distinction between active intervention to cause death and passive refusal to intrude without permission upon a clinically dead patient. See P. Ramsey, The Patient as Person 146-51 (1970) (noting passive euthanasia emphasizes caring for needs of dying, not hastening death).

23. When CPR is begun outside the hospital before the patient is seen by a physician, neurological signs other than consciousness do not correlate with long-term outcome. Sep Earnest, Yarnell, Merrill \& Knapp, Long-tern Survival and Neurologic Status After Resuscitation from Out-ofHospital Cardiac Arrest, 30 Neurology 1298, 1302 (1980). Without either patient consent or predictive criteria for recovery available, clinicians must act on the assumption that a life may be saved by continuing resuscitation efforts. 
Courts should also be wary of a physician's claim of "therapeutic privilege"-that disclosing information necessary to give an informed consent would significantly harm the patient. ${ }^{24}$ Courts must narrowly interpret this privilege if they are not to defeat the very purposes of informed consent, although patient anxiety associated with the dialogue concerning nocoding may be significant. ${ }^{26}$ If honest dialogues about the foreseeable likelihood of a cardiopulmonary arrest were routine, however, patients would come to expect to have such conversations ${ }^{26}$ and would therefore suffer less anxiety from them. Courts should restrict the therapeutic privilege to the relatively rare circumstance where disclosing the required information would significantly harm the patient. ${ }^{27}$

\section{Traditional Tort Remedies}

In theory, courts may impose tort liability upon the negligent physician for failure to attempt resuscitation, for improper resuscitation, or for resuscitation against a patient's will. A negligent failure to attempt resuscitation may subject a physician to liability for wrongful death. ${ }^{28}$ If the physician improperly terminates the professional relationship with the pa-

24. See Capron, Informed Consent in Catastrophic Disease Research and Treatment, 123 U. PA. L. Rev. 340, 387-92 (1974); Meisel, The "Exceptions" to the Inforned Consent Doctrine: Striking a Balance Between Competing Values in Medical Decisionmaking, 1979 WIs. L. REv. 413, 460-61 (1979).

25. Some physicians resisted the traditional informed consent requirements on the ground that patients generally do not want to know about their diagnoses and tests. See, e.g., Kaplan, Greenwald \& Rogers, Neglected Aspects of Informed Consent, 296 NEw ENG. J. MED. 1127 (1977) (arguing that informed consent contributes to morbidity and mortality rates of procedures); Silk, A Physician's Plea: Recognize Limitations of Informed Consent, Am. Med. News, Apr. 12, 1976, at 19, col. 1 (noting informed consent contributes to patient avoidance of surgery for curable brain tumor). Other physicians believe that the patient's lack of choice leads to avoidance of treatment. See, e.g., Crile, Management of Breast Cancer: Limited Mastectomy, 230 J. A.M.A. 95, 95-96 (1974) (maintaining that fear of radical mastectomy is greatest cause of delay in treatment of breast cancer).

26. See S. Bor, Lying: Moral Choices in Public and Private Life 241-46 (1979) (informative conversation that dispels fears more therapeutic than relying upon blind faith); PRESIDENT's Comm'n for the Study of Ethical Problems in Medicine and Biomedical and Behavioral Research, 1 Making Health Care Decisions: A Report on the Ethical and Legal Implications of Informed Consent in the PATIENT-PRActitioner Relationship 96 (1982) (documentation for claims of dangerous effects of informed consent sparse and anecdotal) [hereinafter cited as Making Health Care Decisions]. Furthermore, providing information reduces stress and speeds recovery from surgery. See Making Health Care Decisions, supra, at 100-01 (fewer inhospital recovery days and less medication required for surgical patients who were given more information about surgery).

27. The primary physician should document the reasons for believing that the patient would be harmed by disclosure, as well as the likelihood of the particular type of harm. If a therapeutic exception is necessary, the physician should also obtain informed consent from the patient's family. See Canterbury v. Spence, 464 F.2d 772, 789 (D.C. Cir.) (recommending physician disclosure to close relative if therapeutic privilege invoked), cert. denied, 409 U.S. 1064 (1972).

28. See, e.g., Kern v. Kogan, 93 N.J. Super. 459, 465-66, 226 A.2d 186, 189-90 (1967) (noting statutory provision allowing recovery by kin for wrongful death); Jones v. City of New York, 57 A.D.2d 429, 430, 395 N.Y.S.2d 10, 11 (Sup. Ct. 1977) (allowing award for wrongful death because of inadequate respirator care). 
tient, abandonment creates a separate basis of liability. ${ }^{29} \mathrm{~A}$ battery occurs if the physician resuscitates the patient against expressed wishes. ${ }^{30}$

Despite the widespread use of GPR techniques and coding systems since the early 1960 's, ${ }^{31}$ no plaintiff has asserted any of these tort remedies in the context of $\mathrm{GPR},{ }^{32}$ an unsurprising situation given the ineffectiveness of such remedies in increasing patient participation in coding decisions. Patients generally know little about coding systems or GPR technologies and thus cannot assert their rights to self-determination. Moreover, physicians sometimes resort to subterfuges, such as unwritten or erasable coding systems, ${ }^{33}$ to minimize any tort liability. Disagreements between physicians and patients may not become apparent if the physician need not obtain informed consent for the assignment of a code. ${ }^{34}$ Moreover, obtaining family approval for a no-code assignment, instead of direct consent from the patient, may effectively immunize the physician from liability if the patient dies. ${ }^{35}$ Physicians may also be shielded from liability by community medical standards that allow nondisclosure ${ }^{38}$ and minimal

29. See, e.g., Leesburg Hosp. Ass'n v. Carter, 321 So. 2d 433, 433 (Fla. Dist. Ct. App. 1975) (abandonment alleged for failure of nurses to summon physician for heart attack victim); Levy v. Kirk, 187 So. 2d 401, 402 (Fla. Dist. Ct. App. 1966) (noting that abandonment occurred when physician failed to see patient after hospital admission). Because abandonment is a breach of contract, no expert testimony is required to establish a community standard of practice. By contrast, expert testimony is typically required in a claim of medical negligence. See Alexandridis v. Jewett, 388 F.2d 829 , 833 (1st Gir. 1968) (distinguishing abandonment from negligence).

30. The patient may allege battery in a medical procedure if the physician did not obtain informed consent. See, e.g., Belcher v. Carter, 13 Ohio App. 2d 113, 114, 234 N.E.2d 311, 312 (1967) (radiation treatments); Gray v. Grunnagle, 423 Pa. 144, 155, 223 A.2d 663, 669 (1966) (spinal operation).

31. Sep AMERICAN HeART Ass'n, supra note 12, at vir.

32. Only three court cases to date have directly upheld coding assignments, and all involved instances in which plaintiffs sought to obtain a no-code status for incompetent patients. See Severns v. Wilmington Medical Center, 421 A.2d 1334, 1349 (Del. 1980) (ordering court hearing on requests for no-code order and respirator removal by spouse of comatose patient); In re Minor, 385 Mass. 697, 701, 434 N.E.2d 601, 608 (1982) (allowing physicians to obtain no-code order for abandoned newborn); In re Dinnerstein, 6 Mass. App. Ct. 466, 469-70, 380 N.E.2d 134, 136 (1978) (granting son's, daughter's, and physicians' requests for no-code order on elderly comatose patient).

33. See Le Blang, Does Your Hospital Have A Policy For No-Code Orders?, 9 Legal Aspects MED. PRACTICE 1, 1 (1981) (acknowledging existence in hospitals of informal coding systems); Murphy, Nurses and Nontreatment Decisions, in Dilemmas of Dying: Policies and Procedures for Decisions Not to TREAT 48 (1981) (nurses may be told to delay notifying physicians if patient has cardiac arrest) [hereinafter cited as DrLemmas of Dying]; Van Scoy-Mosher, supra note 11, at 15 (describing use of erasable and "whispered" no-code orders).

34. See infra notes 52 \& 53 (physicians may simply tell patients that procedures will be performed, instead of asking for consent).

35. If assigning the no-code was a potentially criminal act, the family may be reluctant to publicize its complicity. See Robertson, Involuntary Euthanasia of Defective Newborns: A Legal Analysis, 27 Stan. L. REv. 213, 243 (1975).

36. See supra notes 11 \& 12 (little disclosure to patient in most instances). If community disclosure standards are unclear or do not require informed consent, physicians have a practical defense against lawsuits. Cf. Ditlow v. Kaplan, 181 So. 2d 226, 228 (Fla. Dist. Ct. App. 1965) (affirming dismissal of claim because plaintiff offered no evidence on community practice of disclosure); Ross v. Hodges, 234 So. 2d 905, 909 (Miss. 1970) (minimal disclosure by neurosurgeon met community standards). But see Canterbury v. Spence, 464 F.2d 772, 785 (D.C. Cir.) (replacing medical commu- 
treatments. ${ }^{37}$ Finally, defendants may successfully argue that failure to resuscitate cannot be the proximate cause of death of a patient whose heart and lung functions have stopped. ${ }^{38}$

The battery remedy similarly possesses only limited effectiveness. Withholding medical treatment does not constitute battery because there is no nonconsensual contact. ${ }^{30}$ Because patients usually die despite the unwanted invasion of CPR, ${ }^{40}$ they cannot bring suit, and the family may not know of any wrongs or may be too aggrieved to pursue legal action. Most importantly, juries and judges may be unsympathetic to claims arising from heroic actions undertaken by medical personnel to save a life even if taken against the expressed wishes of a dying patient or his family. ${ }^{41}$

\section{Deleterious Results from Current Practice}

Both the resuscitation of a patient who does not desire heroic efforts and the failure to resuscitate a patient who does desire such efforts violate the individual's autonomy. This violation of human dignity is particularly significant because of the life-or-death consequences of the coding choice. ${ }^{42}$ Moreover, the scope of this violation of individual autonomy is likely to increase substantially in the future as CPR techniques become more elaborate and hospitals install more advanced physiological monitoring sys-

nity standard of negligence with judge-made standard), cert. denied, 409 U.S. 1064 (1972).

37. See, e.g., supra note 12 (five-minute resuscitation attempts on elderly patients). Nonresuscitation for terminally ill patients is considered routine care.

38. Cf. A. Holder, Medical Malpractice Law 376 (1978) (no liability if no causal link exists between termination of care and subsequent injury). Damage awards are generally smaller the worse the patient's condition at the time of malpractice. See, e.g., Jones v. City of New York, 57 A.D.2d 429, 431, 395 N.Y.S.2d 10, 12 (Sup. Ct. 1977) (reducing wrongful death damages award because survival of decedent would have been brief); Dunham v. Village of Canisteo, 303 N.Y. 498, 505, 104 N.E.2d 872, 876 (Ct. App. 1952) (noting reduced wrongful death damages if malpractice only hastened death). Since most patients receiving GPR have a poor prognosis, damage awards would thus probably be insufficient deterrents.

39. See Restatement (SEcond) of ToRTs $\S 14$ (1965) (noting necessity of act of contact for battery).

40. See infra note 51 (noting low survival-to-hospital-discharge rate).

41. This is a type of "wrongful life" claim which courts have often rejected. See, e.g., Gleitman v. Cosgrove, 49 N.J. 22, 31, 227 A.2d 689, 693 (1967) (rejecting wrongful life claims by parents and deformed child, because of public policy favoring right to live, despite physicians' negligent failure to warn of birth defect dangers); Williams v. New York, 18 N.Y.2d 481, 482-83, 223 N.E.2d 343, 343-44, 276 N.Y.S.2d 885, 886-87 (Ct. App. 1966) (refusing cause of action for wrongful birth by infant against state for negligent failure to prevent sexual assault on mother in state mental institution); Rieck v. Medical Protective Co., 64 Wis. 2d 514, 518-19, 219 N.W.2d 242, 244-45 (1974) (rejecting wrongful life claim for failure of clinic and physician to determine pregnancy in time for legal abortion).

42. See Superintendent of Belchertown State School v. Saikewicz, 373 Mass. 728, 742,370 N.E.2d 417, 426 (1977) (stating that value of life lessened by failure to allow right to decline medical treatment); In re Eichner, 73 A.D.2d 431, 448, 426 N.Y.S.2d 517, 531 (1980) (warning about danger of technology controlled by strangers who determine definition of death), modified sub nom. Eichner v. Dillon, 52 N.Y.2d 363, 420 N.E.2d 64, 438 N.Y.S.2d 266 (1981). 
tems. ${ }^{48}$ Because most Americans die in a hospital or nursing home rather than in their home, ${ }^{44}$ CPR practice potentially affects a large number of citizens.

Assigning a patient a no-code status without obtaining his approval may amount to ending a human life without consent, ${ }^{45}$ an egregious wrong when that life may be prolonged at small expense. ${ }^{46}$ Such paternalism also denies the individual the opportunity to come to terms emotionally and spiritually with death and dying. ${ }^{47}$ The no-code decision involves true choices, because modern medicine may prolong life in nearly all instances, albeit sometimes with little hope of long-term survival. A no-code determination also intrinsically involves non-medical considerations. A physician's determination of no-codes may therefore result in an imposition of the physician's values that is both inconsistent with patient preferences and unjustified by technical expertise. Under the current system, for example, the likelihood of receiving no-code status increases for those divorced, nonambulatory, or incontinent. ${ }^{48}$

The automatic initiation of GPR efforts on all patients who are not nocoded, by contrast, violates human dignity and the right to bodily integrity of those who do not desire resuscitation. ${ }^{48} \mathrm{CPR}$ may involve electric shock, intubation with artificial respiratory ventilation, and even open-chest in-

43. See Coskey, Cardiopulmonary Resuscitation: Impact on Hospital Mortality-A Ten-Year Study, 129 W.J. MED. 511, 515 (1978) (optimal in theory to monitor every hospital patient); Van Scoy-Mosher, supra note 11, at 14 (noting tendency in medicine to apply new technology indiscriminately when available).

44. See S. BoK, supra note 26, at 244 (more than $80 \%$ of Americans die in hospitals or other institutions); J. ROBERTSON, supra note 10, at 154 (most Americans die in hospitals).

45. See In re Storar, 78 A.D.2d 1013, 1013, 434 N.Y.S.2d 46, 47 (1980) (Cardone, J., dissenting) (noting that depriving individual of compromised life remains a denial of all rights), rev'd, 52 N.Y.2d 363, 420 N.E.2d 64, 438 N.Y.S.2d 266 (1981).

46. See Hahn, Hutchinson \& Conte, Cardiopulmonary Resuscitation in a University Hospital-An Analysis of Surrival and Cost, 131 W.J. MED. 344, 344 (1979) (average cost of resuscitation effort is \$366).

47. See P. RAMSEy, supra note 22 , at 237-38 (advocating cultural recovery of a religious sense that death not always an evil).

48. See Patient Often is Uninvolved in 'No-Code' Choice, Internal Med. News, May 1-14, 1982, at 45 , col. 1. Another study demonstrated that there were greater numbers of resuscitation attempts on all patients at the beginning of the academic year compared with the end of the year, perhaps because of the need for the physician-in-training to acquire and improve upon technical resuscitation skills. See D. Crane, supra note 11, at 80-81. Crane concludes that a physician was less likely to resuscitate the aged because the physician equated advanced age with a decline in social capacity. See id. at 61. Sudnow states that the aged are more frequently pronounced dead after a cursory examination, and noted that alcoholics, prostitutes, drug addicts, and vagrants received less active resuscitation efforts. Sep D. Sudnow, Passing On: The Social Organization of Dying 104-05 (1967).

49. See Pratt v. Davis, 118 Ill. App. 161, 166 (1905) (noting right to inviolability of body), aff'd, 224 Ill. 300,79 N.E. 562 (1906); Superintendent of Belchertown State School v. Saikewicz, 373 Mass. 728, 738-39, 370 N.E.2d 417, 424 (1977) (noting right to freedom from nonconsensual invasion of bodily integrity); In re Eichner, 73 A.D.2d 431, 459, 426 N.Y.S.2d 517, 539 (1980) (noting patient's inherent right to prevent cruel prolongation of dying), modified sub nom. Eichner v. Dillon, 52 N.Y.2d 363, 420 N.E.2d 64, 438 N.Y.S.2d 266 (1981). 
ternal cardiac compression. ${ }^{50}$ Chronically ill patients, who dominate hospital populations, may not wish to undergo CPR measures knowing that even if CPR is "successful," they have little chance of surviving until hospital discharge. ${ }^{51}$

Even physicians who obtain their patients' consent to a coding status need not follow defined requirements that would adequately inform the patient about the nature of GPR procedures, their attendant risks, and the alternative treatments. ${ }^{52}$ An uninformed consent does not recognize the value of individual dignity implicit in autonomous choicemaking and may merely amount to coerced assent..$^{5 s}$ Patients given the opportunity to agree to full-code status without full information may live to regret the outcome. ${ }^{\text {st }}$

\section{A Structural Analysis of the No-Code Decision}

In contrast to the usual treatment of medical decisionmaking as a fiduciary relationship between doctor and patient, this Note adopts a structural analysis which considers the suitability for making the no-code decision of each major actor in the process and criticizes currently available alternatives from a procedural standpoint.

Courts currently rely upon the fiduciary doctrine as a structural description of the physician-patient relationship. ${ }^{.5}$ Unfortunately, courts

50. See In re Minor, 385 Mass. 697, 702, 434 N.E.2d 601, 604-05 (1982) (noting CPR sideeffects include further weakened condition, pain, neurologic and liver damage); In re Dinnerstein, 6 Mass. App. Ct. 466, 468-69, 380 N.E.2d 134, 135-36 (1978) (noting violence and pain intrinsic to GPR).

51. See Coskey, supra note 43 , at 512 (17\% of those receiving CPR survive to hospital discharge); DeBard, Cardiopulmonary Resuscitation: An Analysis of Six Years' Experience and Review of the Literature, 10 ANNALS EMERGEncy MEd. 404, 408 (1981) (24\% rate); Hahn, Hutchinson \& Conte, supra note 46, at 344 (19\% rate); Lemire \& Johnson, Is Cardiac Resuscitation Worthwhile? A Decade of Experience, 286 NEw ENG. J. MED. 970, 970 (1972) (19\% rate).

52. Even those university hospitals which require "informed consent" from the competent patient before assigning no-code status often fail to define what information physicians should divulge. YaleNew Haven Hospital's Do Not Resuscitate Policy, for example, merely recognizes that when physicians initiate conversations about no-coding, they rarely obtain informed consent. Instead, the physician ordinarily tells the patient or family that "there is no reasonable chance of medical reversibility" and asks for "authorization" to assign a no-code status. See Levine, Do Not Resuscitate Orders and Their Implementation, in Dilemmas of Dying, supra note 33, 23, 36-37.

53. See I. BERLIN, Four Essays on LiberTy 121-24 (1969) (defining negative freedom from deliberate interference within area of personal autonomy). But $c f$. Spencer, "Code" or "No Code": A Nonlegal Opinion, 300 NEw ENG. J. MED. 138, 139 (1979) (physician advocating that family members be told why physician will not attempt resuscitation, instead of asking family whether or not they want physician to attempt it).

54. See Füsgen \& Summa, How Much Sense Is There in an Altempt to Resuscitate an Aged Person?, 24 Gerontology 37, 39-42 (1978) (noting that of an original total of 239 elderly patients who underwent an attempted resuscitation, seven of nine survivors at six months beyond hospital discharge would not agree to another resuscitation, while remaining two patients had no opinion).

55. See, e.g., Natanson v. Kline, 186 Kan. 393, 400, 350 P.2d 1093, 1099 (1960) (noting fiduciary relationship requires physician disclosure); Mason v. Ellsworth, 3 Wash. App. 298, 308, 474 P.2d 909, 916 (1970) (noting fiduciary duty to inform). The court in Canterbury v. Spence, 464 F.2d 772, 
ignore the inherent tension between the fiduciary as the ultimate decisionmaker and the patient's right to self-determination. ${ }^{86}$ In informed consent cases, courts tend to balance values, ${ }^{57}$ and the patient's choice often loses out to the preferences of others. ${ }^{88}$

The participants' relative positions and incentives in no-code decisionmaking determine their most effective functions. This relational structure takes into account the increasing emphasis upon patient participation and self-determination in contemporary physician-patient relations. ${ }^{89}$

\section{A. The Patient}

The patient is usually in the best position to evaluate his human needs. ${ }^{60} \mathrm{He}$ can best assess his present physical and emotional pain in

781 (D.C. Cir.), cert. denied, 409 U.S. 1064 (1972), grafted the fiduciary's duty of disclosure onto the physician's duty of care under tort negligence principles.

56. The fiduciary relationship assumes a single stereotyped relationship with an incompetent beneficiary. It is thus clearly incompatible with the notion of autonomy and self-determination.

57. Courts commonly balance individual interests against state interests in determining whether the state should require treatment. See, e.g., In re Spring, 80 Mass. Adv. Sh. 1209, 1220, 405 N.E.2d 115,123 (1980) (balancing incompetent patient's interest in quality of life versus state interest in preservation of life); Superintendent of Belchertown State School v. Saikewicz, 373 Mass. 728, 744-45, 370 N.E.2d 417, 427 (1977) (weighing state interest in preservation of life against individual's freedom to reject intrusions upon privacy and bodily integrity).

58. The traditional judicial weighing of values lends itself to result-oriented decisions with categorical rules. In the case of no-code decisionmaking, such reasoning leads to a particularly difficult choice: Courts must balance the sanctity of life and the patient's autonomy. In the individual case, the emotional, economic, and physical costs of resuscitation may become so overwhelming that to maintain a strict requirement of resuscitation would itself question the "sanctity of life" value by highlighting other dissonant values, such as human dignity. The analysis creates potential tragedy for the terminally ill patient who, if allowed to choose, may wish to have life even momentarily prolonged to see the fulfillment of an important life event. In addition, the technological environment upon which courts base their categorical decisions changes constantly, creating the danger of rapid obsolescence of court-determined cost-benefit calculations. Cf. G. CALABRESI, A COMMON LAW FOR THE AGE OF STATUTES 73 (1982) (commenting on obsolescence of statutes caused by rapid technological changes and difficulties of legislatures in updating these laws). Finally, by concentrating on a result-oriented analysis, courts ignore the independent value of patient participation in the decisionmaking process. Cf. Tribe, Struclural Due Process, 10 HARv. C.R.-C.L. L. REv. 269, 283-89 (1975) (noting that structural due process involves participation of individuals in hearings, apart from the mere application of substantive rules).

59. Compare Kushmer, Doctor-Patient Relationships in General Practice-A Different Model, 7 J. MED. ETHICs 128, 128 (1981) (variety of physician-patient models, including patient participation model, depending on the peculiar situation) and Szasz \& Hollender, A Contribution to the Philosophy of Medicine: The Basic Models of the Doctor-Patient Relationship, 97 ARCHIVES INTERNAL MED. 585, 585 (1956) (patient participation model) with T. PArsons, The Social System 433-54, 463-65 (1951) (traditional model with authoritarian physician and compliant patient).

60. See, e.g., Cobbs v. Grant, 8 Cal. 3d 229, 243, 502 P.2d 1, 10, 104 Cal. Rptr. 505, 514 (1972) (weight given to patient's subjective fears and hopes in evaluating medical risks is a nonmedical judgment reserved to patient); Superintendent of Belchertown State School v. Saikewicz, 373 Mass. 728 , 747, 370 N.E.2d 417, 428 (1977) (describing importance of viewing situational complexities from patient's unique perspective); $c f$. R. Dubos, Mirage of Health: UTopias, Progress, and BioLOGical Change 261 (1979) (disease best measured by individual's ability to function in manner acceptable to himself and not in terms of medical attributes). Furthermore, threatened imposition of intrusive medical technologies may interfere with a patient's psychological ability to come to terms with dying by raising false hopes. See J. WojcIK, Muted ConSENT 113 (1978). 
formulating a decision whether to prolong his life. ${ }^{61}$ Furthermore, in evaluating economic costs, the patient is free from the conflict of interests that beset the family, ${ }^{62}$ the hospital, ${ }^{63}$ or even the state. ${ }^{64}$ Focusing on a patient's desires also avoids difficult evaluations of the patient's social worthiness. ${ }^{65}$ The decision most directly affects the life of the patient, and he should have responsibility for that decision.

\section{B. The Physician}

The physician is best able to determine the viability of the patient and the likelihood of recovery in case of a cardiopulmonary arrest. A decision to no-code a patient is not simply a medical decision, however. Economic ${ }^{68}$ and moral $^{67}$ concerns also deserve consideration. The person most affected by the decision can most adequately assess these factors. Furthermore, physicians left to their own means might consider characteristics of patients that may not be acceptable to the patient or society. ${ }^{68}$ The conscien-

61. Physicians have difficulty in effectively alleviating the pain of dying patients. See $M D$ 's Urged To Aller Prescribing Patterns for Dying Cancer Patients in Pain, Am. Med. News, Feb. 18, 1983, at 2 , col. 1 (citing study that three-quarters of dying patients receiving pain medications continue to experience moderate to severe distress).

62. See, e.g., In re Spring, 80 Mass. Adv. Sh. 1209, 1220 n.3, 405 N.E.2d 115, 122 n.3 (1980) (questioning reliability of decision by ward's wife because of admitted influence of financial cost of nursing home on treatment choice); In re Storar, 52 N.Y.2d 363, 370 n.2, 390, 438 N.Y.S.2d 266, 269 n.2, 279 (1980) (danger of potential abuses of power by a family member).

63. Sep In re Storar, 52 N.Y.2d 363, 390, 438 N.Y.S.2d 266, 279 (1981) (Jones, J., dissenting in part) (extraordinary medical procedures often involve economic cost that may affect hospital's incentive to institute or continue such care).

Physicians may also have financial conflicts of interest in a particular case. Two Los Angeles physicians were criminally prosecuted for unplugging a comatose patient's respirator and passively allowing him to die without nutrition. The'prosecution alleged that the doctors sought to hide a potential malpractice problem that occurred after abdominal surgery which resulted in coma. See Did the Patient Die-Or Was He Murdered?, NewsweEk, Feb. 14, 1983, at 76. The municipal court judge dismissed the charges and noted his reluctance to intervene in a complex medical situation. See Life and Death and the Law, NewsweEk, Mar. 21, 1983, at 52.

64. For example, if Veterans Administration physicians committed a potential malpractice that resulted in a patient's becoming terminally ill, there would be a conflict of interest if the physicians, as government employees, decided to no-code the patient.

65. Cf. In re Spring, 8 Mass. App. Ct. 831, 839, 399 N.E.2d 493, 498 (1979) (value of life should not relate to intelligence or social status), rev'd on other grounds, 80 Mass. Adv. Sh. 1209, 405 N.E.2d 115 (1980); Superintendent of Belchertown State School v. Saikewicz, 373 Mass. 728, 753, 370 N.E.2d 417, 431 (1977) (decision whether to prolong life should not depend on intelligence or social status). But $f f . i d$. at 754, 370 N.E.2d at 432 (1977) (noting that patient's expected pain and disorientation may justify withholding of medical treatment).

66. See P. RAMSEY, supra note 22, at 139 (noting that economic costs, while not turning ethics into a monetary science, do affect the values involved in terminal illness and treatments given).

67. See, e.g., In re Quinlan, 70 N.J. 10, 33-34, 355 A.2d 647, 660 (guardian's Catholic moral viewpoint important in medical decision), cert. denied, 429 U.S. 922 (1976); In re Eichner, 73 A.D.2d $431,440,426$ N.Y.S.2d 517, 526 (1980) (noting that priest-patient accepted Pope's teachings regarding withdrawal of life support), modified sub nom. Eichner v. Dillon, 52 N.Y.2d 363, 420 N.E.2d 64, 438 N.Y.S.2d 266 (1981).

68. See supra note 48 (patient characteristics including marital status, ambulatory status, and perceived moral character affect physicians' decisions).

There are, of course, some disadvantages for the physician in adopting an informed consent stan- 
tious physician may feel more secure in an explicitly stated system of coding and feel more comfortable without the burdens of making crucial nonmedical decisions for patients.

\section{The Patient's Family}

Although it is currently common practice to obtain permission to nocode a patient from a patient's family, ${ }^{69}$ the family is not necessarily in a better position than the patient to evaluate the patient's desire to live. ${ }^{70} \mathrm{~A}$ patient's family is, however, useful in determining what an incompetent patient's desires are or what these desires were prior to incompetency. ${ }^{\mathbf{2 1}}$ The family is also in a better position than the patient to seek legal sanctions for perceived unfairness in the assignment of the no-code status.

\section{The State}

The state has an important interest in promoting the preservation of life. ${ }^{72}$ Since life-saving technologies are available, albeit sometimes only at great cost, this norm may seem compromised by any procedural system allowing patients to die without attempting to prolong their lives. The state's interest in the preservation of life, however, diminishes in decisions involving utilization of invasive technologies on patients already on the

dard. Physicians do not enjoy confronting a patient with questions concerning no-coding or statements describing the patient's terminal condition. They also face additional administrative burdens from documenting the disclosures and consents, and from approaching third-party decisionmakers for further adjudication of controversial issues. The physician may feel threatened by the possibility of lawsuits resulting from standards subject to judicial change; violation of a clearly stated standard could bring civil or even criminal penalties. See 'Do-Not-Resuscitate' Guidelines Issued, Am. Med. News, Oct. 1, 1982, at 13, col. 1. They may be of some use in providing a "community standard" for malpractice decisions, however. See supra pp. 367-68.

69. See In re Dinnerstein, 6 Mass. App. Gt. 466, 475, 380 N.E.2d 134, 139 (1978) (noting that no-coding decision is within competence of physician taking into account patient's history, condition, and family wishes).

70. See Van Scoy-Mosher, supra note 11, at 15 (noting physicians may prolong dying of cancer patients to satisfy family's need to feel physician has employed all possible medical means to save patient). Also, in an extreme case, the patient's family may have either deserted the patient or be unavailable. See, e.g., In re Minor, 385 Mass. 697, 698, 434 N.E.2d 601, 602 (1982) (parents abandoned child patient); In re Quackenbush, 156 N.J. Super. 282, 284, 383 A.2d 785, 786 (Morris County Ct. 1978) (divorced, semi-reclusive patient without family support).

71. See, e.g., In re Severns, 425 A.2d 156, 158 (Del. Ch. 1980) (husband asserting wife's previously expressed wish to die a natural death); In re Spring, 8 Mass. App. 831, 840, 399 N.E.2d 493, 499 (1979) (wife and son part of close knit family with patient), rev'd on other grounds, 80 Mass. Adv. Sh. 1209, 405 N.E.2d 115 (1980); In re Storar, 106 Misc. 2d 880, 885, 433 N.Y.S.2d 388, 393 (Sup. Ct.) (patient's mother empathetic to his needs), aff'd, 78 A.D.2d 1013, 434 N.Y.S.2d 46 (1980), rev'd on other grounds, 52 N.Y.2d 363, 420 N.E.2d 64, 438 N.Y.S.2d 266 (1981).

72. See Roe v. Wade, 410 U.S. 113, 163 (1973) (state's interest in preserving life becomes compelling at the time of fetal viability); In re Quinlan, 70 N.J. 10, 19, 355 A.2d 647, 651-52 (state interest in preserving life has constitutional basis), cert. denied, 429 U.S. 922 (1976); In re Eichner, 73 A.D.2d 431, 450, 426 N.Y.S.2d 517, 533 (1980) (strong public policy to value and protect sanctity of life), modified sub nom. Eichner v. Dillon, 52 N.Y.2d 363, 438 N.Y.S.2d 266 (1981). 
brink of death. ${ }^{73}$ Moreover, the state's interest in preserving life may conflict with certain fundamental values, including the right to bodily integrity, ${ }^{74}$ self-determination, ${ }^{75}$ and privacy. ${ }^{76}$ These rights, unlike the state's interest in preserving life, remain in force even when the death of the individual is certain. The right to bodily integrity is fundamental and may be breached only in certain defined circumstances. ${ }^{77}$ Violations of bodily integrity are often allowed only following an informed consent. ${ }^{78} \mathrm{~A}$ complete GPR attempt requires extremely invasive procedures, yet an individual may cherish privacy in the final moments of life. ${ }^{79}$

73. See In re Severns, 425 A.2d 156, 159 (Del. Ch. 1980) (value of life diminishes if no hope of recovery); In re Quinlan, 70 N.J. 10, 41, 355 A.2d 647, 664 (holding that state interest in life weakens as prognosis dims), cert. denied, 429 U.S. 922 (1976); In re Eichner, 73 A.D.2d 431, 465-66, 426 N.Y.S.2d 517, 543 (1980) (maintaining that patient's lack of health lessens state interest in protection of life), modified sub nom. Eichner v. Dillon, 52 N.Y.2d 363, 438 N.Y.S.2d 266 (1981); cf. In re Quackenbush, 156 N.J. Super. 282, 290, 383 A.2d 785, 789 (Morris County Ct. 1978) (holding that regardless of prognosis, individual's right of privacy against coerced leg amputation overcomes state interest in protection of life).

The avoidance of "passive euthanasia" for nonterminally ill patients is another instance in which the state seeks to preserve human life. Such a policy ignores the tragedy of the present acceptance of passive euthanasia for terminally ill patients who may desperately desire to live. Moreover, prolonging the agonies of patients who want to die does not pay homage to the sanctity of life. The present system both expends scarce medical resources upon those who may not want to live, see supra note 54 (describing results of resuscitation without patient permission), and denies life-saving treatment to those who may desire to be saved. The unnecessary denial of resuscitation may be due to either the failure to obtain direct patient consent, see supra note 11 , or the expenditure of finite medical resources that could be spent on saving the lives of those who intensely desire to be saved, see G. Calabresi \& P. BobbitT, Tragic Choices 189 (1978) (observing that a system that offers "kidneys for everyone" prices these patients' lives exceedingly high compared to the lives of other patients who, for similar expenditures, could also have been saved).

74. See, e.g., Pratt v. Davis, 118 Ill. App. 161, 166 (1905) (right to inviolability of body), aff'd, 224 I1l. 300,79 N.E. 562 (1906); Superintendent of Belchertown State School v. Saikewicz, 373 Mass. 728, 739, 370 N.E.2d 417, 424 (1977) (right to freedom from nonconsensual invasion of bodily integrity).

75. See, e.g., Canterbury v. Spence, 464 F.2d 772, 780 (D.C. Cir.) (fundamental right to determine what is done with own body), cert. denied, 409 U.S. 1064 (1972); Cobbs v. Grant, 8 Cal. 3d 229, 242, 502 P.2d 1, 9, 104 Cal. Rptr. 505, 513 (1972) (right to determine submission to treatment); Schloendorff y. Society of New York Hosp., 211 N.Y. 125, 129, 105 N.E. 92, 93 (1914) (adult's right to determine what shall be done with own body).

76. See Roe v. Wade, 410 U.S. 113, 153 (1973) (noting that woman's decision regarding abortion is protected by fundamental right of privacy); Griswold v. Connecticut, 381 U.S. 479, 485 (1965) (zone of privacy protects distribution of contraceptives); Superintendent of Belchertown State School v. Saikewicz, 373 Mass. 728, 739, 370 N.E.2d 417, 424 (1977) (describing constitutional right of privacy in penumbra of specific Bill of Rights guarantees).

77. This policy applies even to autopsies in the absence of unusual circumstances or informed consent from kin. See, e.g., Wilensky v. Greco, 74 Misc. 2d 512, 512-13, 344 N.Y.S.2d 77, 78 (Sup. Ct. 1973) (Orthodox Jewish parents of deceased enjoined autopsy); Gurganious v. Simpson, 213 N.C. 613, 615-16, 197 S.E. 163, 163-64 (1938) (coroner liable for performing autopsy without consent of parents of deceased).

78. See supra notes 4 \& 15 (requirements of informed consent for invasive medical procedures).

79. See Superintendent of Belchertown State School v. Saikewicz, 373 Mass. 728, 737-38, 370 N.E.2d 417, 423 (1977) (use of measures to prolong life may isolate family from loved one). 


\section{Structural Problems with Past Reform Proposals}

Major proposals for reform would still impede individual choice in nocode decisions. Generalized, objective tests cannot satisfactorily approximate the subjective wishes of individual patients: hospital policies vary greatly and are largely unenforceable; probate courts and hospital ethics committees can neither accommodate large numbers of cases nor provide the requisite monitoring; and living wills have only a limited ability to ascertain and preserve the choices of patients.

\section{A. Current Hospital Policies}

Hospital policies vary broadly in procedures required for no-code decisions. ${ }^{80}$ It is apparently uncommon for a hospital policy to state explicitly that a physician should obtain informed consent from a competent, terminally ill patient prior to assigning a no-code status. ${ }^{81}$ Moreover, no known hospital policy requires a physician to obtain informed consent for resuscitation of all competent patients who are at substantial risk of a cardiopulmonary arrest. Finally, where formal policies and procedures for nocoding do exist, lack of monitoring systems renders such policies largely unenforceable. $^{82}$

If a patient opposes any in-hospital treatments, he may choose to leave the hospital "against medical advice." The inflexibility of choice, how-

80. Accreditation by the Joint Commission on Accreditation of Hospitals does not currently require no-code policies. See JoINT Comm'N ON ACCREdTAtion of Hosps., ACCREditation MaNUAL FOR HOSPITALs 184-88 (1982) (requirements for special care units). Unaccredited community hospitals are not subject to accreditation requirements.

Some of the more sophisticated hospital policies regarding no-coding, which generally originate in university-affiliated hospitals, have been published in the medical literature. None, however, requires that a physician anticipate a probable cardiopulmonary arrest by asking the patient about coding status. Furthermore, no published hospital policy requires informed consent to fully code any patient. All hospital policies allow physicians to obtain no-coding consent as they please. See, e.g., General Care Comm. of the Mass. Gen. Hosp., Optimum Care for Hopelessly Ill Patients, 295 NEw ENG. J. MED. 362, 362 63 (1976) (physician determines treatment category and may voluntarily request advice from Optimum Care Committee); Miles, Cranford \& Schultz, The Do-Not-Resuscitate Order in a Teaching Hospital, 96 ANNAls INTERNAL MED. 660, 660-62 (1982) (how, if at all, to obtain consent ultimately left to physician's judgment); Rabkin, Gillerman, \& Rice, Orders Not to Resuscitate, 295 NEw ENG. J. MED. 364, 365 (1976) (physician obtains informed consent from either patient or family).

81. An unpublished American Bar Association study surveying northern California hospitals shows that hospital policies rarely state such a requirement explicitly. The study probably includes more progressive hospitals than would a nation-wide sample, and therefore is biased in favor of including stricter requirements of informed consent for no-codes. Telephone interview with Dr. Joanne Lynn, Staff Physician on the President's Commission for the Study of Ethical Problems in Medicine and Biomedical and Behavioral Research (Nov. 15, 1982) (notes on file with Yale Law Journal).

82. None of the published hospital policies has an active monitoring system, outside of advisory committees. See supra note 80 .

83. See, e.g., United States v. Iverson, 588 F.2d 194, 194 (5th Cir. 1979) (paranoid schizophrenic convicted of assault occurring a few hours after leaving against medical advice); Williams v. United States, 450 F. Supp. 1040, 1041 (D.S.D. 1978) (Veterans Administration hospital held negligent for 
ever, forces the patient either to undergo resuscitation against his will while in the hospital or to suffer an unnecessary risk of a shortened lifespan by leaving needed medical facilities. ${ }^{84}$

\section{B. Hospital Ethics Committees and Probate Courts}

Court decisions have equated the requirements for informed consent in terminations of life-maintenance technology and in no-code decisions. ${ }^{85}$ This reasoning would logically lead to the adoption of the procedure mandated by the Quinlan court: the hospital ethics committee would make every initial decision, based upon the physician's and family's recommendations. ${ }^{88}$ Other courts, however, have recommended using probate courts to sanction life-terminating decisions either by patients or by their guardians. ${ }^{87}$

allowing murderer to sign out against medical advice without warning police); Kirk v. Commonwealth, 186 Va. 839, 844, 44 S.E.2d 409, 411 (1947) (husband allowed to sign out schizophrenic wife against medical advice).

84. Furthermore, hospitals and physicians have not uniformly adopted formal discharge procedures, and no standardized monitoring devices exist to check against abuses or imposed biases. See Schlauch, Reich \& Kelly, Leaving the Hospital Against Medical Advice, 300 NEw ENG. J. MED. 23 (1979) (poor, single, black patients left against medical advice in disproportionately high numbers); Smith, Discharge Against Medical Advice from an Acute Care Private Psychiatric Hospital, $38 \mathrm{~J}$. Clinical Psychology 550, 550 (1982) (noting correlation of numbers of patients allowed to leave against medical advice with particular attending physician). Patients may also be ill-informed of the risks that they incur if they do sign out against medical advice. Initiation of a patient advocacy program reduces the rate of hospital discharges against medical advice. See Targum, Capodanno, Hoffman \& Fourdraine, An Interiention to Reduce the Rate of Hospital Discharges Against Medical Advice, 139 AM. J. Psychiatry 657, 657 (1982). Finally, patients who are nonambulatory or without community social support, including caring relatives or economic backing, may be precluded from exercising the option of leaving the hospital. See, e.g., R. BuRT, supra note 11, at 9-10 (blind and nonambulatory burn patient, David G.).

85. See, e.g., Severns v. Wilmington Med. Center, 421 A.2d 1334, 1343-50 (Del. 1980) (failing to distinguish between removal of respirator and no-code order); In re Quinlan, 70 N.J. 10, 29, 355 A.2d 647, 663 (analogizing respirator removal decision to no-code decision), cert. denied, 429 U.S. 92 (1976).

86. See In re Quinlan, 70 N.J. 10, 55, 355 A.2d 647, 672, cert. denied, 429 U.S. 92 (1976). The Quinlan court was confronted with a patient in a "chronic persistent vegetative state" who nonetheless did not meet brain death criteria. See Quinlan, 70 N.J. at 24, 355 A.2d at 654 . Relying upon the medical experts' belief that death would likely occur if physicians removed the artificial respiratory support, see id. at 25, $355 \mathrm{~A} .2 \mathrm{~d}$ at 655, the Quinlan court vested decisionmaking authority in a hospital ethics committee as a means of diffusing responsibility and as a monitoring mechanism against any improper motives by the family or physician, see id. at $49-51,355$ A.2d at 668-69. The court acknowledged the present legal assumption that no-code decisionmaking fits within the Quinlan paradigm. See id. at 39, 355 A.2d at 663 (finding no distinction between decisions involving lifesustaining and those involving resuscitation technologies). Unlike traditional informed consent principles, the Quinlan paradigm applies to incompetent patients. See id. at 41, 355 A.2d at 664 (noting patient unable to exercise choice because incompetent). An exception to the Quinlan paradigm is where rare neurologic diseases may destroy respiratory functions but leave intact intellectual functions, as in the case of a man who suffered from amyotrophic lateral sclerosis. See Satz v. Perlmutter, 362 So. 2d 160 (Fla. Dist. Ct. App. 1978) (allowing patient to consent to removal of respirator), aff'd, 379 So. 2d 359 (Fla. 1980).

87. See, e.g., Superintendent of Belchertown State School v. Saikewicz, 373 Mass. 728, 756-59, 370 N.E.2d 417, 433-35 (1977) (proposing that denial of life-prolonging treatment should be made initially by probate courts); In re Eichner, 73 A.D.2d 431, 476-77, 426 N.Y.S.2d 517, 550 (1980) 
There are, however, material structural elements distinguishing the removal of life-maintenance technology from no-code decisions. First, nocode decisions occur more frequently ${ }^{88}$ and may overwhelm a procedural system unable to accommodate a large number of cases. Second, if a physician is unable to obtain a no-code decision, he can use subterfuges not available in the decision to remove life-maintenance technologies, such as transferring the patient to a facility that lacks CPR teams, ${ }^{80}$ running a minimal CPR effort, ${ }^{90}$ and using unwritten or erasable coding systems. ${ }^{91}$ The monitoring of no-code decisionmaking must therefore be administratively uncumbersome, or physicians will resort to subterfuges. Hospital ethics committees and probate courts, however, are both cumbersome ${ }^{92}$ and passive. ${ }^{93}$ Third, no-code decisions require an immediate judgment, while decisions to remove life-sustaining devices are subject to less urgent time restraints. The decision not to resuscitate must be made in advance of the unpredictable timing of a cardiopulmonary arrest. ${ }^{94}$ Once a patient is already on life-maintenance technologies, however, time for deliberation exists. ${ }^{95}$

(recommending probate hearing after appointed guardian and committee of doctors certify that the patient is in terminal condition), modified sub nom. Eichner v. Dillon, 52 N.Y.2d 363, 420 N.E.2d 64, 438 N.Y.S.2d 266 (1981).

88. A coding decision is made, implicitly or explicitly, for every patient who enters a hospital. By contrast, physicians rarely place patients on life-maintenance technologies. See Chipman, Adelman \& Sexton, Criteria for Cessation of CPR in the Emergency Department, 10 ANNALS EMERGENCY MED. 11,16 (1981) (determining that incidence of severe brain damage with coma among successful resuscitations averages five per cent).

89. See In re Minor, 385 Mass. 697, 704, 713, 434 N.E.2d 601, 605, 610 (1982) (transfer to foster home equivalent to assigning no-code order, because foster parents unable to get child to hospital in time for resuscitation); In re Dinnerstein, 6 Mass. App. Ct. 466, 467 n.1, 380 N.E.2d 134, 135 n.1 (1978) (most nursing homes lack CPR teams).

90. See Baer, supra note 12, at 1065 (physician advocating five-minute resuscitation attempts on all patients over the age of 65 ).

91. See supra note 33 (describing erasable and unwritten coding systems).

92. Committees are cumbersome because of the delay in assembling decisionmakers and in reaching a reasoned decision. The courts, of course, generally have an ultimate decisionmaker, in the form of a judge, at hand. Nonetheless, the parties must find attorneys, and the attorneys must familiarize themselves with the case.

93. Because both ethics committees and courts depend upon the parties to bring the controversy before the decisionmaker, they are inherently passive institutions.

94. A cardiopulmonary arrest may occur with little warning. See $\mathrm{K}$. ISSELBACHER, R. AdAMS, E. Braunwald, R. Petersdorf \& J. Wilson, Harrison's Principles of Internal Medicine (9th ed. 1980) (describing sudden deaths from cardiovascular collapse).

95. Indeed, physicians and families seek removal of life-sustaining devices mainly because of the long-term prospects of patients who continue to need them. The prognosis of a comatose patient incrementally dims with passing time, while intensive-care costs mount. See President's Comm'N for the Study of Ethical Problems in Medicine and Biomedical and Behavioral ReSEARCH, DEFINING DEATH 96-97 (1981) (summarizing studies of outcomes of comatose patients); $c f$, e.g., In re Quinlan, 70 N.J. 10, 25-26, 355 A.2d 647, 655 (describing chronic intensive care unit treatment with little likelihood of restoration to cognitive life), cert. denied, 429 U.S. 922 (1976); In re Eichner, 73 A.D.2d 431. 436-37, 426 N.Y.S.2d 517, 524 (1980) (comatose patient in intensive-care unit with little sign of gaining consciousness), modified sub nom. Eichner v. Dillon, 52 N.Y.2d 363, 438 N.Y.S.2d 266 (1981). 
Finally, no-code systems implicitly involve all patients, whereas Quinlan-type procedures involve only incompetent patients. ${ }^{96}$ If the individual desires of a patient are of paramount concern, third-party decisionmaking by the hospital committee or probate court is therefore less necessary in no-code decisions, since the vast majority of admitted hospital patients are competent.

\section{G. Living Wills}

Living wills are signed documents in which a person requests that his life not be unnecessarily prolonged if he becomes terminally ill. ${ }^{97}$ Thirteen states and the District of Columbia have passed "natural death acts"98 acknowledging the legitimacy of living wills. Living wills cannot, however, combine sufficient flexibility with enough specificity to incorporate necessary procedural safeguards. An unpredictable medical condition may, by itself, have such a significant impact on a patient's decision so as to make every real circumstance sui generis. ${ }^{99}$ Social and economic situations may change rapidly in a medical crisis. Because living wills depend upon voluntary advance initiation by the individual patient without solicitation by the physician, they cannot have the necessary comprehensive scope in influencing all coding decisions. ${ }^{100}$

96. Karen Quinlan's brain was damaged in the areas controlling cognition and respiration, but not in the region controlling internal body regulation. See In re Quinlan, 70 N.J. 10, 24-25, 355 A.2d 647, 654-55, cert. denied, 429 U.S. 922 (1976). But cf. supra note 86 (rare neurological diseases leaving intact intellectual functions but destroying respiratory functions).

97. There are generally other restrictions on the sort of treatment which the patient may refuse. The refused medical measures must usually serve only to prolong life. See, e.g., IDAHo Code $\S 39$ 4504 (Supp. 1982) (living will applies only to procedures that merely prolong moment of death); Nev. Rev. Stat. $\$ 449.610$ (1977) (limiting application to when death is imminent). Children, incompetents, or pregnant women generally may not make living wills. See, e.g., DEL. CodE ANN. tit. 16 , $\$ 2502$ (a) (Supp. 1982) (limiting applicability to competent adults); KAN. STAT. ANN. $\$ 65-$ 28,103 (1979) (prohibiting enforcement of written declaration if patient pregnant). As with conventional wills, the presence of a certain number of witnesses may be necessary. See, e.g., ALA. CoDE $\S$ 22-8A-4(a) (Supp. 1982) (requiring that witnesses be two non-relatives at least 19 years old); CAL. HEALTH \& SAFETY CODE $\$ 7188$ (West Supp. 1982) (requiring that witnesses include two nonrelatives who may not be health providers).

98. Sep Ala. Code $\S \S 22-8 A-1$ to -10 (Supp. 1982); ARK. Stat. ANN. $\$ \S 82-3801$ to -3804 (Supp. 1981); Gal. Health \& Safety Code $\$ \S 7185-7195$ (West Supp. 1982); D.C. Code ANN. $\S \S 6-2401$ to -2430 (Supp. 1982); Del. CodE ANN. tit. 16, $\S \S 2501-2509$ (Supp. 1982); IDAHo CoDE $\S \S 39-4501$ to -4508 (Supp. 1982); Kan. Stat. ANN. $\$ \S 65-28,101$ to $-28,109$ (1979); NEv. Rev. Stat. \$\$ 449.540-.690 (1977); N.M. Stat. AnN. $\$ \S 24-7-1$ to -11 (1978); N.C. Gen. Stat. $\S \S 90-320$ to -322 (Supp. 1981); OR. Rev. Srat. $\S \S 97.050-.085$ (1977) (amended 1979); TEX. REV. Civ. Stat. ANN. art. 4590h (Vernon Supp. 1982); Vt. Stat. AnN. tit. 18, \$§ 5251-5262 (Supp. 1982); Wash. Rev. Code ANN. $\$ \S 70.122 .010-.905$ (Supp. 1982).

99. See Van Scoy-Mosher, supra note 11, at 15 (acknowledging difficulty in foreseeing circumstances surrounding one's death). One's social and economic condition may change dramatically with illness as well.

100. See Canterbury v. Spence, 464 F.2d 772, 783 n.36 (D.C. Gir.) (noting that physician must volunteer information because confusion or fear often inhibits patients), cert. denied, 409 U.S. 1064 (1972). By the time the patient realizes that death is a possible outcome, it may be too late to begin the process required to write a living will. 


\section{Toward Patient Gontrol Over No-Code Decisionmaking}

This Note proposes a model consistent with the previously discussed structural considerations. Choices exist for both the competent terminally ill and the non-terminally ill patient. All patients should determine their own coding status at the time of hospital admission. Clear disclosure standards and the use of monitoring systems, including second medical opinions and review by patient advocates, will facilitate preservation of patient choice. Gourts will need to restructure liability rules to incorporate the proposed changes in medical decisionmaking.

\section{A. Recognizing That Choices Exist}

Contrary to the current medical community presumption that nonterminally ill patients should never be assigned no-code status, the Note proposes that all competent patients should retain the choice to receive a no-code status after hearing an informed appraisal of their prognoses, the nature of GPR procedures, and the risks and benefits of resuscitation. Patients should be allowed to decide that the risks and benefits of heroic resuscitation efforts do not justify the intervention, because the patients can best take into account the quality of their own lives and the benefits and disadvantages of prolonging their existence should they suffer a cardiopulmonary arrest in the hospital. ${ }^{101}$

On the other hand, terminally ill patients should not be no-coded against their will. Prolonging life should remain an alternative, even if one with little hope. ${ }^{102}$ An individual may earnestly be awaiting an expected future event, such as the birth of a grandchild, and might be willing to bear all possible costs in hopes of living long enough to experience this last joy. The knowledge that one has a terminal illness may also affect an individual's consent to treatments as well as to the coding decision. ${ }^{103}$ If informed consent is to have substantive meaning, courts should require disclosure of the determination that a patient is terminally ill. ${ }^{104}$

101. See supra pp. 371-72,

102. This is contrary to the present judicial presumption that there is no choice available for the terminally ill patient with an irreversible condition. See, e.g., In re Dinnerstein, 6 Mass. App. Ct. 466, 474-75, 380 N.E.2d 134, 138-39 (1978) (describing medical situation of no hope or chance); In re Quinlan, 70 N.J. 10, 47-48, 355 A.2d 647, 667-68 (describing no treatment as only choice for dying patients), cert. denied, 429 U.S. 922 (1976).

103. In effect, this Note proposes that in addition to requiring disclosure of risks, nature of procedures, and available alternatives, physicians should also be required to disclose a patient's prognosis. Without knowledge of present prognosis, evaluation of future risks is less meaningful. The patient may wish to forego a procedure or treatment that would provide only temporary success.

104. Cf. Schneckloth v. Bustamonte, 412 U.S. 218, 284-85 (1973) (Marshall, J., dissenting) (noting defendant's consent to police search cannot be meaningful choice unless he knew in fact that he could exclude police); Miranda v. Arizona, 384 U.S. 436, 464-65 (1966) (holding that defendant cannot make free and knowing choice to remain silent under Fifth Amendment because of police 


\section{B. Eliciting the Patient's Decision}

Merely answering a patient's questions does not satisfy a physician's duty to disclose. ${ }^{108}$ Physicians must directly inquire about a patient's feelings regarding coding status after fully informing him about CPR measures. Clarity and specificity safeguard both the patient's and the physician's interests in decisionmaking. Obtaining every patient's consent upon admission to the hospital would allow more time for deliberation and ensure that consent is obtained before the patient becomes incompetent.

An attending physician should also clearly document the nature of the patient's illness and prognosis as well as the patient's desires after his physician has given him a reasonably thorough appraisal of CPR measures. ${ }^{106}$ The physician should repeat this procedure whenever the patient's medical condition changes materially. ${ }^{107}$ Physicians and the other hospital staff members should clearly document all resuscitation efforts, as well as the circumstances of in-hospital deaths. The chief of the medical department should routinely review these reports.

For incompetent patients, waiting for a probate court to appoint a guardian may not be feasible if cardiopulmonary arrest occurs shortly after admission. It may therefore be necessary to appoint a guardian ex ante for such occasions ${ }^{\mathbf{1 0 8}}$ or to make the designation on the basis of the nearest kin. ${ }^{108}$ Such a solution avoids the difficulty present in living wills of having to anticipate all possible situations. ${ }^{110}$ Modifications to the proposed

failure to inform of rights).

105. See supra p. 370.

106. A clear, unambiguous coding determination on the front of the patient's medical chart is necessary to alert all hospital personnel who must react immediately should a cardiopulmonary arrest occur. Such a record would also facilitate monitoring by physicians and patient advocates who later review that record.

107. The proximity of the choice of coding assignment to the cardiopulmonary arrest is important. Cf. Eichner v. Dillon, 52 N.Y.2d 363, 378-80, 420 N.E.2d 64, 72, 438 N.Y.S.2d 266, 274 (1981) (patient's statement of desires in close proximity to operation is highly probative of choice not to have life prolonged). The decision by a competent patient remains in force if incompetency ensues prior to the cardiopulmonary arrest, because the original choice was based on an informed evaluation of possible contingencies, including the possibility that incompetency would precede a cardiopulmonary arrest.

108. See Van Scoy-Mosher, supra note 11, at 16 (recommending that everyone have a guardian).

109. A designation on a basis that uses an established hierarchy avoids confusion if multiple family members are available for consent. There may be an exception to the nearest-kin designation when the spouse has initiated divorce proceedings against the patient.

110. A guardian, familiar with the patient's personality and lifestyle, may be the individual best suited to choose what the patient would have desired. Additionally, the guardian's decision may have special legitimacy directly derived from an appointment by the patient for these particular purposes. See, e.g., In re Eichner, 73 A.D.2d 431, 439, 426 N.Y.S.2d 517, 526 (1980) (fellow priest closest companion familiar with patient priest's wishes), modified sub nom. Eichner v. Dillon, 52 N.Y.2d 363, 420 N.E.2d 64, 438 N.Y.S.2d 266 (1981); In re Storar, 106 Misc. 2d 880, 885, 433 N.Y.S.2d 388,393 (Sup. Ct.) (accepting fact that adult patient's mother was sensitive to his needs), aff'd, 78 A.D.2d 1013, 434 N.Y.S.2d 46 (1980), rev'd on other grounds, 52 N.Y.2d 363, 420 N.E.2d 64, 438 N.Y.S.2d 266 (1981). 
procedure may be necessary when the patient is a child ${ }^{111}$ or a pregnant woman. ${ }^{112}$

\section{Preserving a Patient's Choice}

To reduce the possibility of judgmental error or even personal bias, ${ }^{113}$ a second attending physician's concurrence with the nature of the illness and the prognosis should be required before an assignment of a no-code status. ${ }^{114}$ To encourage independent responsibility, this physician should be held jointly and severally liable for negligence in this evaluation. The peer review by a second physician adds an element of monitoring to the no-

111. Children should be assigned a full-code status based upon their best interests if it is significantly likely that CPR will result in a life without serious mental and physical disabilities. See, e.g., Jehovah's Witnesses v. King County Hosp. Unit, 278 F. Supp. 488, 497-98 (W.D. Wash. 1967) (ordering blood transfusions for child against parental religious objections), aff'd, 390 U.S. 598 (1968); People ex rel. Wallace v. Labrenz, 411 Ill. 618, 625, 104 N.E.2d 769, 773 (ordering blood transfusions for anemic child), cert. denied, 344 U.S. 824 (1952); In re Sampson, 29 N.Y.2d 900, 901, 278 N.E.2d 918, 918-19, 328 N.Y.S.2d 686, 687 (1972) (per curiam) (overruling parental objections to anticipated blood transfusions during surgery); $c f$. J. Goldstein, A. Freud \& A. Solnit, Before THE BEST INTERESTS OF THE CHILD 95-96 (1979) (describing unpublished court decision that allowed adult mother to choose death, while requiring treatment for her newborn).

Parents need not surrender their parental autonomy if the dying child's life would only be prolonged for a short time during which a normal quality of life would be impossible. See, e.g., Schowalter, Ferholt \& Mann, The Adolescent Patient's Decision to Die, 51 Pediatrics 97, 97-98 (1973) (describing teenager with irreversible kidney disease who was allowed to die by abstaining from life-extending hemodialysis treatments). No-coding a child should require informed consent by the parents. A child's rejection of life-saving treatment therefore cannot represent a truly informed consent. Mature emancipated minors should be allowed to determine their coding status based upon their own individual desires. An emancipated minor is generally defined as economically independent, not living with parents, and having parents who have surrendered their parental duties and rights. See A. Holder, Legal Issues in Pediatrics and Adolescent Medicine, 139-41 (1977).

112. Pregnancy adds an additional dimension to the issues of no-coding. The state's interest in protecting fetal life after viability may require a CPR effort on the mother with institution of lifesupport systems until a Caesarean section is performed. See Colautti v. Franklin, 439 U.S. 379, 386, 388 (1979) (state interest becomes compelling when fetus attains viability). But a woman's interest in her privacy and bodily integrity outweigh medical interests in invasions on behalf of a nonviable fetus. See Roe v. Wade, 410 U.S. 113, 162-64 (1973) (holding that state may intervene in abortion decision in second trimester of pregnancy only to protect health and safety of pregnant woman). Although fetal viability may occur earlier than 28 weeks of gestation, see Colautti v. Franklin, 439 U.S. 379,387 (1979) (noting fetal viability usually exists at 28 weeks, but may occur at 24 weeks), this is not true in most cases, and it is impossible to make individual determinations without invading the woman's body. Viability is defined by the fetus's ability to survive outside the mother's body. See Roe v. Wade, 410 U.S. 113, 160 (1973). Hence, the state should not interfere with a pregnant woman's informed no-code decision prior to the 28th week of pregnancy. In the second trimester, chances for fetal survival increase dramatically if life support systems of a brain-dead mother can be maintained for an additional one to three weeks to attain the twenty-seventh week of gestation. See Dillon, Lee, Tronolone, Buckwald \& Foote, Life Support and Maternal Brain Death During Pregnancy, $248 \mathrm{~J}$. A.M.A. 1089 (1982) (presenting two case studies of brain-dead pregnant women). Physicians should therefore obtain informed consent from the mother, unless already incompetent, for CPR and life support measures in anticipation of this possibility.

113. See supra note 48.

114. Accuracy of diagnosis and prognosis is crucial to the no-code decision. Cf. In re Quinlan, 70 N.J. 10, 51, 355 A.2d 647, 669 (prognosis is focal point of decision to remove life support), cert. denied, 429 U.S. 922 (1976). Even if the prognosis is unclear, the ambiguity of prognosis is nevertheless an important factor for the patient to consider. 
code decision without resort to more complex bureaucratic approaches, such as committee reviews, which probably cannot in any case guarantee perfect accountability. ${ }^{115}$ Clarification of procedures by itself functions to limit abuse.

A patient advocate, preferably with a nurse's training, ${ }^{116}$ should also screen all involved medical charts within twenty-four hours after the physician certifies that the necessary conditions exist for a no-code assignment. The patient advocate should also review no-code orders on a regular basis. A patient should be able to rescind a no-code order at any time.

\section{Changing Legal Liability Rules}

Courts should award a substantial minimum amount of tort damages, based on a cause of action in battery, ${ }^{117}$ to the plaintiff for violation of human dignity if physicians attempt to resuscitate him without obtaining his informed consent reasonably soon after his admission to the hospital. ${ }^{118}$ If the patient consents to a full-code status, however, there is in effect an assumption of risk for resulting medical and emotional costs that may result from a CPR effort, ${ }^{119}$ unless there is negligence in the CPR performance. Failure to honor a full-code decision or failure to obtain informed consent for a no-code assignment should result in civil ${ }^{120}$ or even

115. Cf. G. Calabresi \& P. BobbitT, supra note 73 , at 189 (monitoring of decentralized medical decisions generally relies on physician professionalism and an informal system of peer review).

116. Nurses are ideal patient advocates because their training incorporates sophisticated medical knowledge with a high degree of patient contact. Nurses, as advocates, may have a viewpoint and identity apart from physicians. See generally H. FEIFEL, NEw MEanings of DeAth 135-40 (1977) (commenting on possible important roles of nurses in caring for the dying); B. HutTManN, ThE Patient's Advocate (1981) (nurse author describing techniques of patient advocacy).

117. See F. HARPER \& F. JAMES, 1 ThE LAw OF TorTs $\S 3.2$, at 213 (1956) (battery theory protects physical integrity from harm and freedom from offensive bodily contact). The plaintiff need only prove nonconsensual bodily invasion. See Plant, An Analysis of "Infonned Consent," 36 ForDHAM L. REV. 639, 657-58 (1968). If informed consent to be fully coded is not obtained, and CPR measures are performed, a substantial minimum compensation for battery should be awarded as well. Cf. Goldstein, supra note 7, at 691 (reduction of patient's power of choice is a harm to his dignity even if same decision would be made and no physical injury incurred). But cf. Canterbury v. Spence, 464 F.2d 772, 791 (D.C. Cir.) (using negligence and determining causality by what a prudent person in patient's position would have decided if suitably informed), cert. denied, 409 U.S. 1064 (1972); Cobbs v. Grant, 8 Cal. 3d 229, 244-46, 502 P.2d 1, 11-12, 104 Cal. Rptr. 505, 515-16 (1972) (using same objective test); Natanson v. Kline, 187 Kan. 186, 190-91, 354 P.2d 670, 673 (1960) (requiring that plaintiff establish that she would not have taken treatments if informed).

118. This substantial minimum amount of tort damages must be sufficient to compensate the plaintiff for the costs of litigation as well as to discourage coding violations. Proof of negligence is not a requirement for battery. Strict liability forces the hospital and physicians to bear the costs of all accidents, because they are in the best position to reduce the costs of accidents and the costs of accident prevention. See G. Calabresi, The Costs of Accidents 26-31 (1977) (describing principal function of accident law as the reduction of the sum of accident costs and costs of avoiding accidents).

119. $C f$. W. Prosser, LAw OF TORTs 450 (1971) (describing application of assumption of risks if choice is voluntary and free).

120. While withholding medical treatment does not constitute battery, there may be a violation of a physician's duty of care if abandonment occurs. See In re Spring, 80 Mass. Adv. Sh. 1209, 1218, 405 N.E.2d 115, 122 (1980). 


\section{No-Code Decisionmaking}

criminal penalties. ${ }^{121}$ The proposed system more sharply defines these liability rules compared to the present system, which suffers from nonuniformity and a lack of explicitly defined coding procedures. The clarity of these proposed rules would provide adequate notice to potential violators. ${ }^{122}$

\section{Concluston}

This Note urges a more honest and accountable treatment of a patient's desires. The values of self-determination and autonomy should not diminish in importance with the approach of death. Failure to honor these values renders the competent patient incompetent through lack of knowledge and robs the patient of human dignity through lack of choice. The dying patient should determine what is precious, whether it be a heroic intervention or an acknowledgment of privacy and bodily integrity.

-Dean M. Hashimoto

121. See supra note 63 (criminal prosecutions of physicians).

If a tort victim requests a no-code status and subsequently dies from the previously sustained injuries, the actions of the tortfeasor remain the proximate cause of the victim's death. This is similar to the tortfeasor's liability for further injuries from medical malpractice. See, e.g., Modave v. Long Island Jewish Med. Center, 501 F.2d 1065, 1072 (2d Gir. 1974) (acknowledging that negligent driver normally liable for hospital malpractice injury to accident victim); Lebesco v. Southeastern Penn. Transp. Auth., 251 Pa. Super. 415, 422-23, 380 A.2d 848, 852 (1977) (noting that tortfeasor liable for additional injury from unskillful medical treatment). The same is true if a crime victim requests a no-code status. $C f$, e.g., In re J.N., 406 A.2d 1275, 1279 (D.C. App. 1979) (discontinuing life support system of patient does not amount to intervening cause of death); People v. Gulliford, 86 III. App. 3d 237, 241, 407 N.E.2d 1094, 1097-98 (1980) (nontreatment for pneumonia not supervening cause of death); Commonwealth v. Golston, 373 Mass. 249, 256, 366 N.E.2d 744, 749-50 (1977) (disconnection of respirator not proximate cause of death of patient).

122. Cf. Keeler v. Superior Court, 2 Cal. 3d 619, 633, 470 P.2d 617, 626, 87 Cal. Rptr. 481,490 (1970) (holding that fetal killing not murder because due process requires clear notice for changes in definition of homicide); In re Eichner, 73 A.D.2d 431, 451, 426 N.Y.S.2d 517, 533 (1980) (discussing legal need for notice by allowing advanced prosecution in determination of whether withdrawal of treatment constitutes homicide), modified sub nom. Eichner v. Dillon, 52 N.Y.2d 363, 420 N.E.2d 64, 438 N.Y.S.2d 266 (1981). 